\title{
Intraperitoneal urinary bladder fistula caused by a Foley catheter: a successfully conservative management
}

\author{
Yi-Chun Lin, ${ }^{1}$ Yen-Chung Lin ${ }^{2}$ \\ 1Department of Internal Medicine, Taipei City Hospital, Ren-Ai Branch, Taipei, Taiwan \\ ${ }^{2}$ Department of Internal Medicine, School of Medicine, College of Medicine, Taipei Medical University, Taipei, Taiwan
}

Correspondence to Dr Yen-Chung Lin, yclin0229@tmu.edu.tw

\section{DESCRIPTION}

A 93-year-old man presented with gross haematuria for 1 month. The urine analysis showed numerous RBCs in microscopy. The renal function was normal and urine cytology revealed nothing. Tracing the patient's history it was found that he had received radical prostatectomy 20 years ago, but he denied any other trauma or surgery history. An indwelling catheter followed by normal saline irrigation was started. The cystoscopy showed a perforated ulcer in the urinary bladder (figure 1). After the procedure, he suffered from sudden onset of abdominal guarding pain. Abdominal/pelvic CT scan revealed that a urethral Foley catheter went through the urinary bladder into peritoneum with fluid accumulation in the cul-de-sac area (figure 2). Catheter drainage alone was performed under consideration of minimal injury and old age. The patient became stabilised after 2 months of empiric antibiotics and parenteral nutrition supply.

Catheter-induced urinary bladder fistula is a rare and serious complication mostly due to a prolonged use of indwelling urethral catheter in the literature. ${ }^{1}$ In this case, intraperitoneal urinary bladder fistula caused by a shortterm indwelling Foley catheter had never been reported. Intraperitoneal urinary bladder rupture with a sudden upset of intra-abdominal pressure results in abdominal compartment syndrome and decreased cardiac or renal function. ${ }^{2}$ The increased pressure results in rupture of the

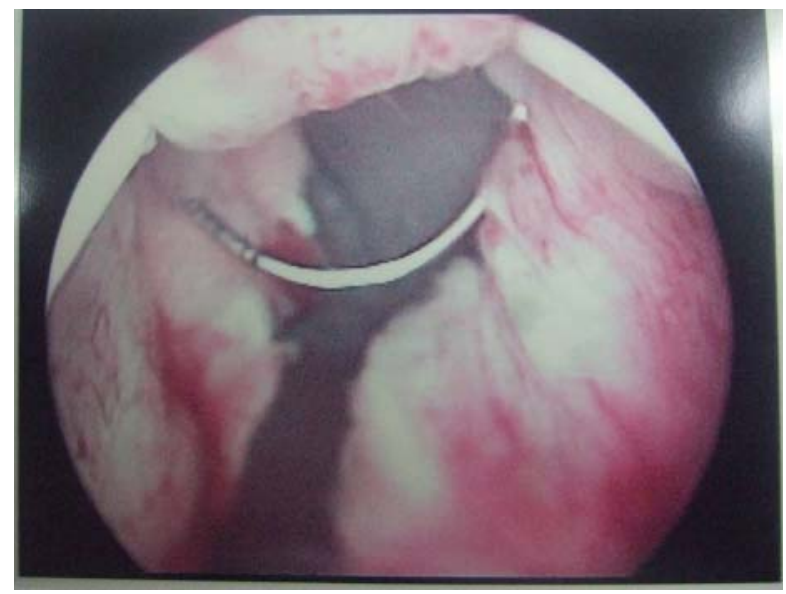

Figure 1 Cystoscopy showing a perforated ulcer over the urinary bladder.

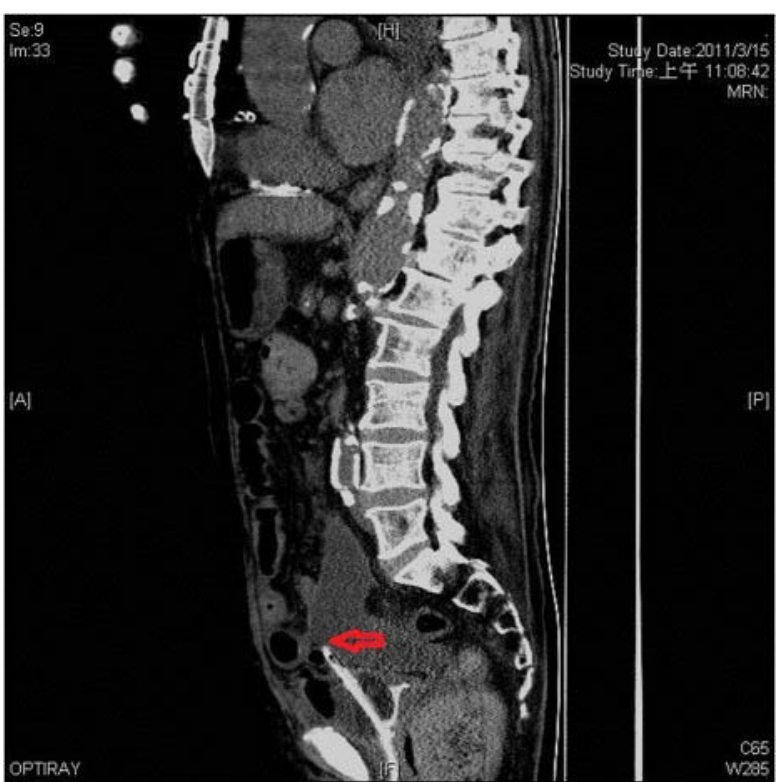

Figure 2 CT of the abdomen showing a dwelling urinary catheter went through the bladder into intraperitoneum space with fluid filling the cul-de-sac (arrow).

dome, the weakest and most movable part of the bladder. Surgical repair is the first treatment choice of intraperitoneal urinary bladder perforation but catheter drainage alone can be applicable to minimal iatrogenic injuries ${ }^{3}$ as demonstrated in this case.

\section{Learning points}

- Intraperitoneal fistula created by short-term Foley catheter with successful conservative management was rarely reported and this is the reason why we demonstrated this case.

- Patients with prior bladder or prostate disease should be careful about Foley catheter implantation.

Competing interests None

Patient consent Obtained. 


\section{BMJ Case Reports}

\section{REFERENCES}

1. Merguerian PA, Erturk E, Hulbert WC Jr, et al. Peritonitis and abdominal free air due to intraperitoneal bladder perforation associated with indwelling urethral catheter drainage. J Urol 1985; 134:747-50.
2. Meldrum DR, Moore FA, Moore EE, et al. Prospective characterization and selective management of the abdominal compartment syndrome. Am J Surg 1997; 174:667-72.

3. Gomez RG, Ceballos L, Coburn M, et al. Consensus statement on bladder injuries. BJU Int 2004;94:27-32.

This pdf has been created automatically from the final edited text and images.

Copyright 2012 BMJ Publishing Group. All rights reserved. For permission to reuse any of this content visit http://group.bmj.com/group/rights-licensing/permissions.

BMJ Case Report Fellows may re-use this article for personal use and teaching without any further permission.

Please cite this article as follows (you will need to access the article online to obtain the date of publication).

Lin Y-C, Lin Y-C. Intraperitoneal urinary bladder fistula caused by a Foley catheter: a successfully conservative management. BMJ Case Reports 2012;10.1136/ bcr.01.2012.5630, Published XXX

Become a Fellow of BMJ Case Reports today and you can:

- Submit as many cases as you like

- Enjoy fast sympathetic peer review and rapid publication of accepted articles

- Access all the published articles

- Re-use any of the published material for personal use and teaching without further permission

For information on Institutional Fellowships contact consortiasales@bmjgroup.com

Visit casereports.bmj.com for more articles like this and to become a Fellow 